\title{
Influence of packaging and potassium sorbate on the physical, physicochemical and microbiological alterations of guava preserves
}

\author{
Influência da embalagem e do sorbato de potássio sobre as \\ alterações físico-químicas e microbiógicas de doce em massa de goiaba \\ Camila Carvalho MENEZES ${ }^{1 *}$, Soraia Vilela BORGES ${ }^{1}$, Fabiana Queiroz FERRUA ${ }^{1}$, \\ Carolina Pimentel VILELA ${ }^{2}$, João de Deus Souza CARNEIRO ${ }^{1}$
}

\begin{abstract}
The elaboration of preserves through fruit processing is a promising alternative for their conservation. Such processing provides pleasant flavor due to the increase of sweetness and allows good conservation of the product for a prolonged time. Seeking quality and higher durability of fruit preserves, the purpose of this work was to evaluate the interference of potassium sorbate addition, and polypropylene, metallic and cellophane film packaging on the quality of guava (Psidium guajava L.) preserves during storage, through the physical, physiochemical and microbiological characteristics. The physical, physiochemical and microbiological analyses showed that the different types of packaging did not interfere in the stability of the guava preserves until the $5^{\text {th }}$ month of storage - time being the factor that most influences the quality of the preserves when stored under temperature and humidity of $19.6^{\circ} \mathrm{C}$ and $76.2 \%$, respectively. The potassium sorbate caused an increase of the soluble solid levels and a decrease of the water activity. Regardless of the treatment, the preserves remained microbiologically stable during storage.
\end{abstract}

Keywords: guava preserves; storage; stability.

\section{Resumo}

A elaboração de doces através do processamento de frutas é uma alternativa promissora para a sua conservação pelo fato de proporcionar um sabor agradável, com o aumento da doçura, e permitir uma boa conservação do produto por tempo prolongado. Diante da busca por qualidade e maior durabilidade de doces de frutas, o objeto do trabalho foi avaliar a interferência da adição de sorbato de potássio e das embalagens de polipropileno, metálicas e de filmes de celofane sobre a qualidade, por meio das características físicas, químicas e microbiológicas do doce em massa de goiaba (Psidium guajava L.) durante o armazenamento. As análises físicas, químicas e microbiológicas mostraram que os diferentes tipos de embalagens não interferiram na estabilidade do doce de goiaba em massa até o $5^{\circ}$ mês de armazenamento, sendo o tempo, o fator que mais influenciou na qualidade do doce quando armazenado em temperatura e umidade de $19,6{ }^{\circ} \mathrm{C}$ e $76,2 \%$, respectivamente. O sorbato de potássio ocasionou um aumento do teor de sólidos solúveis e diminuição da atividade de água. Independente do tratamento, os doces permaneceram microbiologicamente estáveis durante o armazenamento.

Palavras-chave: doce em massa de goiaba; armazenamento; estabilidade.

\section{Introduction}

Guava is the one of the most important cultivations in tropical and subtropical countries. According to Sato, Sanjinéz-Argandonã and Cunha (2004), Brazil is one of the largest world producers of the fruit, together with other countries such as Mexico, Pakistan and India. The State of São Paulo is the largest guava producer in the country, with six thousand planted hectares, representing $70 \%$ of the national production. The high perishability, together with the lack of available storage during the peak industrial processing /harvest months, contribute to postharvest losses of around $30 \%$. Therefore, the industrialization of products such as jellies and preserves is a good alternative for the production surplus.
Preserves are the result of the appropriate processing of the edible parts of vegetables, with added sugars, water, pectin ( 0.5 to $1.5 \%$ ), $\mathrm{pH}$ adjuster (3 to 3.4 ), besides other ingredients and permitted additives until reaching adequate consistency, assuring product stability. After the processing, the preserves should be packaged properly and stored under environmental conditions (JACKIX, 1988; ASSOCIAÇÃO BRASILEIRA DAS INDÚSTRIAS DE ALIMENTAÇÃO, 1996). Guava jam or preserves should have color characteristic of the product, varying from yellowish red to brownish red, odor and characteristic flavor reminiscent of guava and a gelatinous and solid appearance, allowing cutting (MORI; YOTSUYANAGI; FERREIRA, 1998).

'Departamento de Ciências dos Alimentos, Universidade Federal de Lavras - UFLA, CEP 37200-000, Lavras, MG, Brazil, e-mail: camilacarvalhomenezes@yahoo.com.br;

sborges@dca.ufla.br; fqueiroz@dca.ufla.br; joaodedeus@dca.ufla.br

${ }^{2}$ Engenheira de Alimentos, Universidade Federal de Lavras - UFLA, Lavras, MG, Brazil, e-mail: lucarbela@yahoo.com.br

${ }^{*}$ Corresponding author 
The shelf life of a product represents the period in which the product maintains good sensorial and microbiological conditions for consumption, without offending taste or compromising the health. Those conditions depend on the physical, chemical and microbiological transformations that occur during storage, which depend on the nature of the product, the components of the mixture, the packaging and the storage conditions (temperature, relative humidity, duration) (KANNAN; THIRUMARAN, 2004; WICKLUND et al., 2005). In dealing with foods such as juices, compotes and jellies, their conservation is usually achieved by the combined application of barriers such as $\mathrm{pH}$ reduction, water activity reduction by the addition of solutes, thermal treatment and use of preservatives (STILES BATTEY; DUFFY; SCHAFFNER, 2002).

The type of packaging in which the product is conditioned can also influence its shelf life. Packaging should avoid the product sensorial characteristics alterations, besides meeting marketing, cost, and availability needs, among others. In cases in which hot packaging of the product is done - in order to decrease the oxygen concentration in the free space and the microbial load of the packaging - it is also required that the packaging material have thermal and dimensional stability at the filling temperatures. Besides those requirements, good hermeticity of the closing system assures the maintenance of the packaging material characteristics and avoids the microbiological recontamination of the product (JAIME et al., 1998).

Facing the search for quality and higher durability of fruit preserves, the objective of this work was to evaluate the interference of the addition of potassium sorbate and polypropylene, metallic and cellophane film packaging on the quality of guava (Psidium guajava $\mathrm{L}$ ) preserves during storage.

\section{Materials and methods}

\subsection{Experimental design}

A triple factorial layout was followed, with 2 repetitions, whose appraised factors were: $\mathrm{X}_{1}$ : formulations (absence and presence of potassium sorbate); $\mathrm{X}_{2}$ : packaging (metallic, polypropylene and cellophane); $\mathrm{X}_{3}$ : storage times $(0,30,90$ and 150 days).

\subsection{Elaboration of the preserves}

Ripe guavas from the 'Pedro Sato' cultivar were used, at an advanced stage of maturation, acquired from producers of the Associação dos Fruticultores de Lavras (FRUTILAVRAS), 2007 harvest, stored for 24 hours under refrigeration until processing. The ingredients used were the following: crystal type sugar (commercial), monohydrated citric acid P.A. (commercial brand NUCLEAR), high metoxilated citric pectin (commercial brand VETEC) and potassium sorbate (commercial brand VETEC). The flowchart in Figure 1 contains the elaboration stages of the preserves.

The fruits were washed under running water, sanitized in $200 \mathrm{mg} . \mathrm{L}^{-1}$ sodium hypochlorite solution for 15 minutes, selected and pulped in an electric pulper $(0.06 \mathrm{~mm}$ diameter sieve) Macanuda ${ }^{\circ}$ manufacture, model DM-Ji.

The formulation of the preserve was established as described by Menezes et al. (2009). The preserves were processed in an open stainless steel pot, to which the pulp and sugar were added. The pectin ( $0.5 \%$ in relation to the pulp in all treatments) and the citric acid ( $0.5 \%$ in relation to the pulp in all treatments) were incorporated to the preserves in the end of the cooking process to avoid pectin degradation due to acidity and high temperature. Potassium sorbate was added to the preserves dissolved in a pulp portion (on average, four pulp to one sorbate portions) when the preserves presented a concentration of around $50^{\circ} \mathrm{Brix}$. The addition of potassium sorbate respected the limit from the Brazilian legislation, that is, maximum of $0.1 \%$ of the final product (BRASIL, 2001). The preserves were cooked until they reached a soluble solid level of $73^{\circ}$ Brix.

After the cooking process, the preserves were wrapped in polypropylene packaging $(0.190 \mathrm{~mm}$ thick, $9.0 \mathrm{~cm}$ diameter and $5.5 \mathrm{~cm}$ long $)$, metallic packaging with tinplate body $(0.189 \mathrm{~mm}$ thick, 9.8 diameter $\mathrm{mm}$ and $7.0 \mathrm{~cm}$ long), cover and bottom in metallic chrome leaf ( $0.202 \mathrm{~mm}$ thick), and in colorless cellophane film $(0.020 \mathrm{~mm}$ thick). The filling and closing were made while the product was still hot. The preserves were molded in the cellophane film with the aid of the polypropylene packaging that served as a base until the total cooling of the preserves. Soon after that, the packaging was properly identified and stored in cold chamber at $19.6{ }^{\circ} \mathrm{C}$ and relative humidity of approximately $76.2 \%$. Since one of the purposes of this work was to assist the small scale producers from the area in order to improve the quality of their products, the temperature and humidity values were established according to the averages of the Climatological Norms (1961-1990) over thirty years in the region of Lavras, State of Minas Gerais. Such data were supplied by the Principal Climatological Station of Lavras, in liaison with UFLA/INMET. In spite of the attempt to standardize the relative humidity during the study, using a cold chamber with controlled temperature and humidity, the hygrometer revealed a variation of the relative humidity between 76 and $83 \%$.

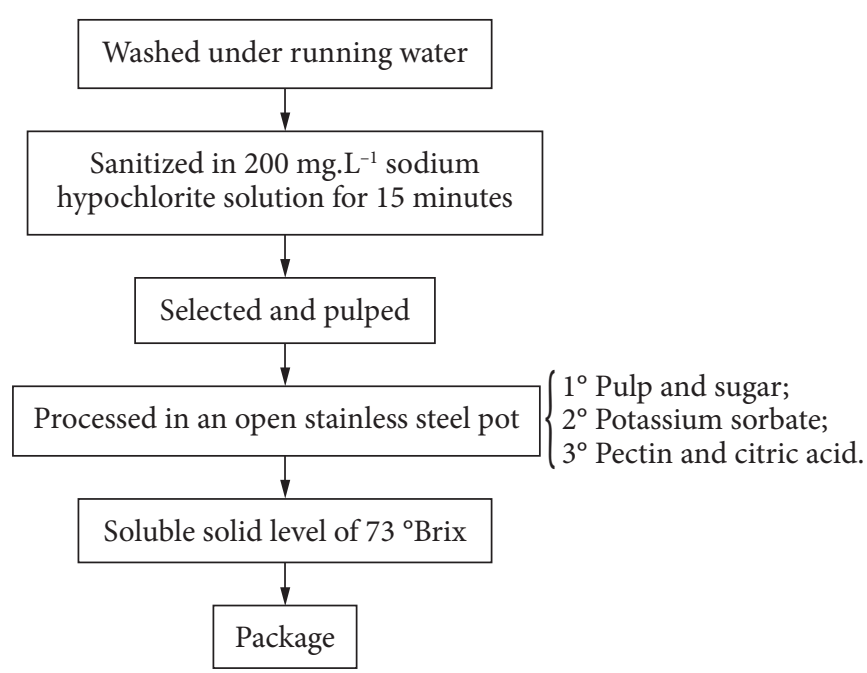

Figure 1. Flowchart of guava preserve production. 
The analyzed formulations are shown in Table 1, and each one (presence and absence of potassium sorbate) was analyzed for the three packaging types and for the 4 storage times $(0,30$, 90 and 150 days).

\subsection{Physicochemical analyses}

The $\mathrm{pH}$ was determined by a digital potentiometer $\left(\mathrm{Tecnal}^{\circ}\right.$ model TEC-3P-MP), according to the Instituto Adolfo Lutz (1985). The titratable acidity determination was accomplished according to the technique described by the Association of Official Analytical Chemists (1992) and expressed as the equivalent of citric acid per $100 \mathrm{~g}$ of sample. The determination of the soluble solids was made by refractometry ( Tecnal $^{\circ}$ model AR-200), according to the analytical norms of IAL (INSTITUTO ADOLFO LUTZ, 1985) and the results were expressed in ${ }^{\circ}$ Brix. The water activity was determined using Aqualab equipment (Decagon model $3 \mathrm{TE}$ ), where samples of approximately $5 \mathrm{~g}$, were carefully placed in plastic containers and the readings were conducted under a controlled temperature of $19.0 \pm 0.3^{\circ} \mathrm{C}$. The determinations of those analyses were made in triplicate.

\subsection{Texture Profile Analysis (TPA)}

TPA was accomplished using a TA.TX2i Stable Micro Systems texture analyzer, (Goldaming, England), with flat-bottomed cylindrical aluminum probe $(\varnothing=45 \mathrm{~mm})$ and time, distance, pre-test, test and post-test speeds of 5 seconds, $6 \mathrm{~mm}, 2 \mathrm{~mm} / \mathrm{s}, 1 \mathrm{~mm} / \mathrm{s}$ and $2 \mathrm{~mm} / \mathrm{s}$, respectively. In order to carry out the readings, the samples were cut into $1 \mathrm{~cm}^{3}$ pieces. The results of the force $\times$ time curve were calculated by the software program Texture Expert - version 1.22. The parameters analyzed were the following: firmness, cohesivity, elasticity, adhesiveness and fracturability. The results expressed are averages of eight determinations.

\subsection{Color analysis}

The color of the preserves was determined according to the methodology proposed by Giese (1996). The values of $\mathrm{L}^{*}$ and $\mathrm{a}{ }^{*}$ were determined with a Minolta, model CR 400 colorimeter, working with $\mathrm{D}_{65}$ (daylight) and using the CIELab standards: in which $L^{*}$ varies from 0 (black) to 100 (white) and $a^{*}$ varies from green (-) to red (+). The values of $b$ * were also obtained, however, they were not appraised because, according to Padula and Rodriguez-Amaya (1987), in the case of guava, which has as predominant red color due to the high amount of lycopene present, the value ${ }^{*}$ is much more representative of the color than $b$ *. Sato, Sanjinéz-Argandonã and Cunha (2006) also determined in preliminary studies that the yellow color $\left(b^{*}\right)$ does not present a significant difference during the guava processing in sucrose syrup. Therefore, in this work, $b^{*}$ was not determined.

\subsection{Microbiological analyses}

The determinations of Salmonella sp. and total coliforms at $35^{\circ} \mathrm{C}$ were carried out according to Silva, Junqueira and Silveira (1997) and the surface serial dilution technique (SANSÓN, 2000) was used for the fungi and yeasts determinations.

\subsection{Statistical analysis}

The results were analyzed through Analysis of Variance, where the significance of the main effects and interactions was observed. Regression analysis was specifically used to determine the alterations of the treatments during shelf life and the $F$ test was used to evaluate the effect of potassium sorbate, because, as there are only two levels, this is already conclusive (PIMENTEL-GOMES, 1990). The statistical analyses were carried out with the aid of SISVAR program (FERREIRA, 2000).

\section{Results and discussion}

In Tables 2 and 3 the summaries of the variance analyses are presented (ANOVA) with their respective significance levels, variation coefficients and average values for each variable response, obtained starting from the experimental results of the physiochemical and physical analyses, respectively.

The $\mathrm{pH}$ values of the preserves did not vary during the 5 months of shelf life, and there were no significant interferences $(\mathrm{p} \leq 0.05)$ of the packaging type and presence of potassium sorbate. The average $\mathrm{pH}$ of the preserves was equal to 3.41 (Table 2). Policarpo et al. (2007a) also verified that the $\mathrm{pH}$ values of umbu preserves remained constant during storage, as well as Assis et al. (2007), in studies on the stability of cashew jam during 120 days of storage. It is known that the stability of sorbic acid in food systems is highly influenced by the $\mathrm{pH}$ of the medium (THAKUR; SINGH; ARYA, 1994); however, in spite of the $\mathrm{pH}$ of the guava preserves of the present study being similar to values (between 3.5 and 4.5) where there are reports of high degradation of acids, such as sorbic acid, in sugar solutions (GERSCHENSON; ALZAMORA; CHIRIFE, 1986), Vidyasagar and Arya (1983) verified that, except for citric acid and malic acid, all the other acids exhibit a catalytic effect on its degradation, and the effect of the specific acid seems to be more important than the effect of the $\mathrm{pH}$ on the degradation of this preservative. Therefore, the choice of the citric acid as the acidulant of this product can be an important factor for the preservation of its physical, sensorial and microbiological characteristics.

In spite of the stability of the $\mathrm{pH}$, there was a significant increase in the titratable acidity of the preserves (Figure 2) during storage, agreeing with Nascimento, Oliveira and Borges (2002) on the study of the physiochemical alterations during the conservation of passion fruit cut peel preserves.

The presence of potassium sorbate reduced the water activity of the preserves (Table 4). Gliemmo, Campo and Gerschenson (2006) also determined in their studies that the addition of potassium sorbate in aqueous model systems provokes a

Table 1. Composition of the guava preserve formulations.

\begin{tabular}{lcc}
\hline \multicolumn{1}{c}{ Components } & \multicolumn{2}{c}{ Formulations } \\
\cline { 2 - 3 } & F1 & F2 \\
\hline Potassium sorbate (\%) & 0 & 0.1 \\
Pulp/sugar ratio $\left(\mathrm{g}^{-1}{ }^{-1}\right)$ & 50 & 50 \\
Citric acid (\%) & 0.5 & 0.5 \\
Pectin (\%) & 0.5 & 0.5 \\
Soluble solids ( ${ }^{\circ}$ Brix) & 73 & 73 \\
\hline
\end{tabular}


reduction of the water activity, mainly in the presence of glucose. The $\mathrm{a}_{\mathrm{w}}$ was not influenced by the packaging material and storage time, possibly due to the relative humidity value used in the experiment (between 76 to $83 \%$ ) being in equilibrium with the water activity of the preserves ( 0.77 on average).

Table 2 shows that the interaction between time and the presence or absence of potassium sorbate was significant $(\mathrm{p}<0.05)$ for the level of soluble solids. As potassium sorbate is soluble in water (THAKUR; SINGH; ARYA, 1994), the increase of that parameter (Figure 3 ) for the preserves with sorbate presence can be explained by the presence of that salt in the medium. However, in spite of the fact that the syneresis was not quantified during the storage, the elevation of the soluble solid levels throughout time can be attributed to that phenomenon, which is a problem frequently verified in fruit pulp gels, resulting from the liberation of the water maintained in the gel matrix (FIZMAN; DURAN, 1992; MOUQUET; DUMA; GUILBERT, 1992; MOUQUET et al., 1997).

During the five months of storage, there were no significant interferences of the packaging and potassium sorbate on the color parameters (Table 3 ). The storage of the preserves in cold chamber, without the effect of illumination, might have prevented that the different \% of light transmission of the packaging (ALVES et al., 2007) interfere in the conservation process. However, there was significant interference $(\mathrm{p}<0.05)$

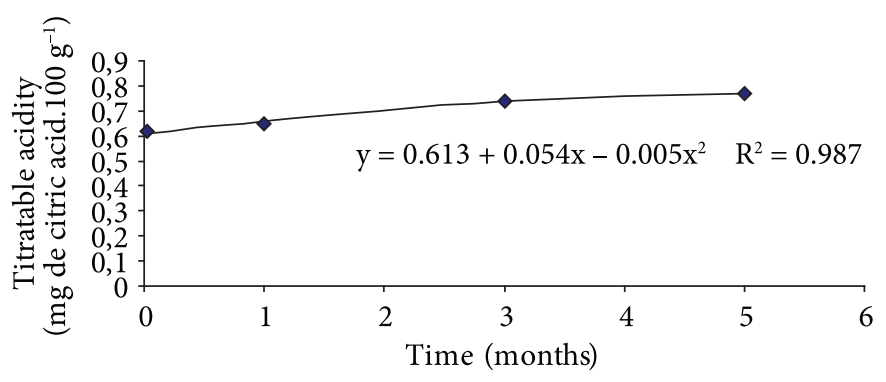

- Titratable acidity observe — Titratable acidity estimate

Figure 2. Graphic representation, regression equation and coefficient of determination of the titratable acidity as a function of storage time.

Table 2. Levels of significance, coefficient of variation and average values of the physicochemical variables of guava preserves.

\begin{tabular}{|c|c|c|c|c|c|}
\hline \multirow[t]{3}{*}{ Causes of variation } & \multicolumn{5}{|c|}{ Levels of significance } \\
\hline & \multirow[t]{2}{*}{$\mathrm{DF}$} & \multicolumn{4}{|c|}{ Variables } \\
\hline & & $\mathrm{pH}$ & TA & $a_{w}$ & SS \\
\hline Time $(\mathrm{T})$ & 3 & 0.1295 & $0.000^{*}$ & 0.2273 & $0.0000^{\star}$ \\
\hline Sorbate $(S)$ & 1 & 0.9042 & 0.5617 & $0.0073^{\star}$ & $0.0000^{\star}$ \\
\hline Packaging $(\mathrm{P})$ & 2 & 0.3218 & 0.7194 & 0.9634 & 0.9192 \\
\hline $\mathrm{T}^{\star} \mathrm{S}$ & 3 & 0.0986 & 0.4093 & 0.9315 & $0.0000^{*}$ \\
\hline $\mathrm{T}^{\star} \mathrm{P}$ & 6 & 0.4675 & 0.9149 & 0.9707 & 0.8234 \\
\hline $\mathrm{S}^{*} \mathrm{P}$ & 2 & 0.3206 & 0.5318 & 0.8058 & 0.5066 \\
\hline $\mathrm{T}^{\star} \mathrm{S}^{\star} \mathrm{P}$ & 6 & 0.4218 & 0.7514 & 0.9907 & 0.9375 \\
\hline Error & 24 & & & & \\
\hline Total corrected & 47 & & & & \\
\hline $\mathrm{CV}(\%)$ & & 4.88 & 4.93 & 2.69 & 2.30 \\
\hline General average & & 3.41 & 0.70 & 0.77 & 73.48 \\
\hline
\end{tabular}

${ }^{*}$ Value of $F$ test significant to nominal value of $5 \%$ probability; TA - titratable acidity ; $\mathrm{a}_{\mathrm{w}}-$ water activity; SS - soluble solids.

Table 3. Levels of significance, coefficient of variation and average values of color and texture variables of guava preserves.

\begin{tabular}{|c|c|c|c|c|c|c|c|c|}
\hline \multirow[t]{3}{*}{ Causes of variation } & \multicolumn{8}{|c|}{ Levels of significance } \\
\hline & \multirow[t]{2}{*}{ DF } & \multicolumn{7}{|c|}{ Variables } \\
\hline & & $\mathrm{L}^{*}$ & $\mathrm{a}^{*}$ & FIR & $\mathrm{COE}$ & EL & $\mathrm{AD}$ & FR \\
\hline Time (T) & 3 & $0.0053^{*}$ & $0.000^{*}$ & 0.9811 & 0.2737 & 0.3133 & $0.0175^{\star}$ & 0.8934 \\
\hline Sorbate (S) & 1 & 0.1001 & 0.0503 & 0.0594 & 0.3670 & 0.3767 & 0.4952 & 0.1075 \\
\hline Packaging $(\mathrm{P})$ & 2 & 0.8789 & 0.8698 & 0.9455 & 0.4628 & 0.1281 & 0.7971 & 0.5126 \\
\hline $\mathrm{T}^{\star} \mathrm{S}$ & 3 & 0.9701 & 0.5032 & 0.7290 & 0.8780 & 0.6382 & 0.1122 & 0.9422 \\
\hline $\mathrm{T}^{\star} \mathrm{P}$ & 6 & 0.6564 & 0.9747 & 0.9481 & 0.9798 & 0.2698 & 0.8188 & 0.9832 \\
\hline $\mathrm{S}^{\star \mathrm{P}}$ & 2 & 0.3570 & 0.8356 & 0.5862 & 0.8071 & 0.3809 & 0.6777 & 0.8689 \\
\hline $\mathrm{T}^{\star} \mathrm{S}^{\star} \mathrm{P}$ & 6 & 0.7045 & 0.8481 & 0.9939 & 0.7072 & 0.3233 & 0.7456 & 0.9040 \\
\hline Error & 24 & & & & & & & \\
\hline Total corrected & 47 & & & & & & & \\
\hline $\mathrm{CV}(\%)$ & & & 14.38 & 29.15 & 26.77 & 6.81 & -20.28 & 50.03 \\
\hline General average & & & 18.73 & 469.30 & 0.19 & 0.87 & -211.33 & 398.17 \\
\hline
\end{tabular}

${ }^{*}$ Value of $F$ test significant to nominal value of $5 \%$ probability; $L^{*}$ - color L; a - color a; FIR - firmness; COE - cohesivity; EL - elasticity; AD - adhesivity; FR - fracturability. 
of the storage time, but it was not possible to adjust a good model to the data regarding the variation of luminosity during storage, since the number of points studied (4 times) did not allow adjusting a higher order model. According to the averages presented (Table 5) a tendency of decline was verified for the luminosity values; in other words, there was a darkening of the preserves during storage. Similar results were found in works done with strawberry jam (GARCIA-VIGUERA et al., 1999; WICKLUND et al., 2005) and with umbu pulp preserves (POLICARPO et al., 2007b).

The indexes of the red coloration of the preserves $\left(a^{*}\right.$ ) increased with time (Figure 4 ), as in the work by Garcia-Viguera et al. (1999) in determining that the degradation rate of the value $\mathrm{CIE} \mathrm{a}^{*}$ is not always correlated to the degradation rate of the anthocyanin (pigment) in strawberry jam. It was demonstrated that the concentration of polymeric pigments increases with the temperature and time of storage, and that it has an important effect on the color of juices and red wines (SOMERS, 1971; ADANS; ONGLEY, 1973; BAKKER; TIMBERLAKE, 1986; WITHY et al., 1993).

In relation to the texture, only the adhesiveness presented a significant decrease (in absolute values) during the storage of the preserves (Table 3). The stability of the other parameters, which was pointed out by the variance analysis $\mathrm{p} \leq 0.05$, is possibly attributed to the high values of the coefficients of variation (CV) (Table 3). This fact can be a result of the difficulty in maintaining the several processing stages strictly standardized, what can be an object of study in subsequent works. Figure 5 illustrates the behavior of the adhesiveness of the preserves during the five months of storage. The adjusted model was linear, due to the fact that the determination coefficient and significance index values of the model presented be satisfactory. A decrease of the adherence was verified during storage, in other words, a higher facility of detachment of the piston from the sample occured.

The treatments remained microbiologically stable during the 150 days of storage. The results indicated the absence of Salmonella sp. and a non-significant occurrence of total coliforms (<3 NMP.g $\left.{ }^{-1}\right)$, fungi and yeasts $\left(<10 \mathrm{UFC}^{-1}\right)$. This stability is possibly due to the intrinsic characteristics

Table 4. Effect of potassium sorbate on water activity of guava preserves.

\begin{tabular}{cc}
\hline Potassium sorbate & $\mathrm{a}_{\mathrm{w}}$ (water activity) \\
\hline Absence & $0.7790^{\mathrm{b}}$ \\
Presence & $0.7615^{\mathrm{a}}$ \\
\hline
\end{tabular}

Averages followed by the same letter in the same column are equal among themselves by the $F$ test $(\leq 0.05)$.

Table 5. Averages of CIE $L^{\star}$ value during storage times.

\begin{tabular}{cc}
\hline Time (months) & Color L $^{*}$ \\
\hline 0 & 35.7875 \\
1 & 33.3377 \\
3 & 34.8892 \\
5 & 32.8862 \\
\hline
\end{tabular}

of guava preserves, such as low $\mathrm{pH}(\mathrm{pH}=3.41)$, low water activity (between 0.76 and 0.78 ) and high soluble solids level (73 ${ }^{\circ}$ Brix), besides the satisfactory sanitary condition during the processing.

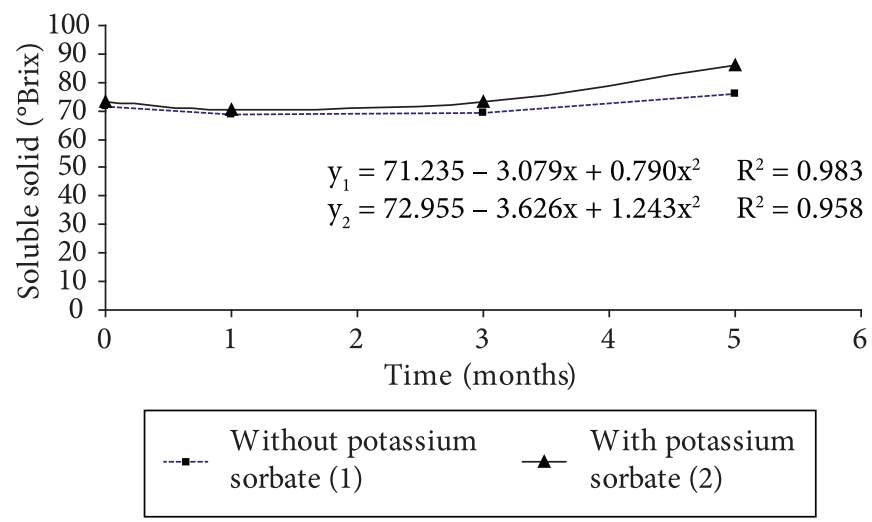

Figure 3. Graphic representation, regression equation and coefficient of determination of soluble solid levels as a function of storage time and the presence of potassium sorbate.

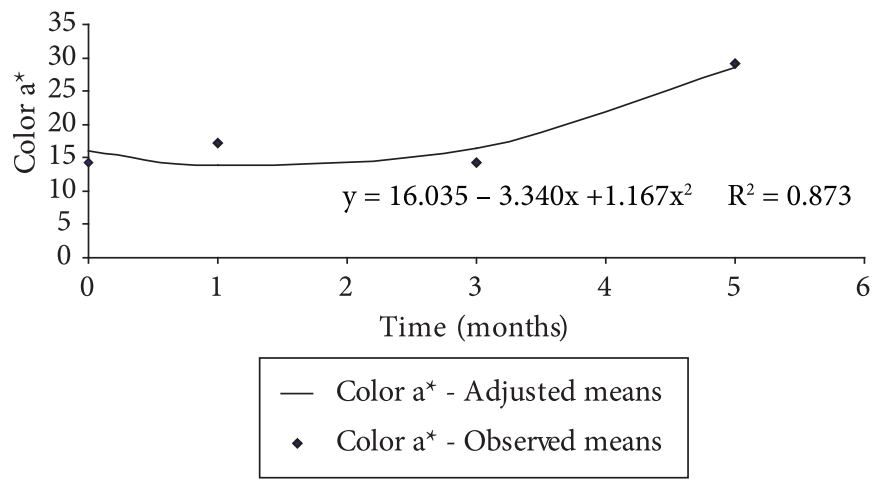

Figure 4. Graphic representation, regression equation and coefficient of determination of the color $\mathrm{a}^{*}$ as a function of storage time.

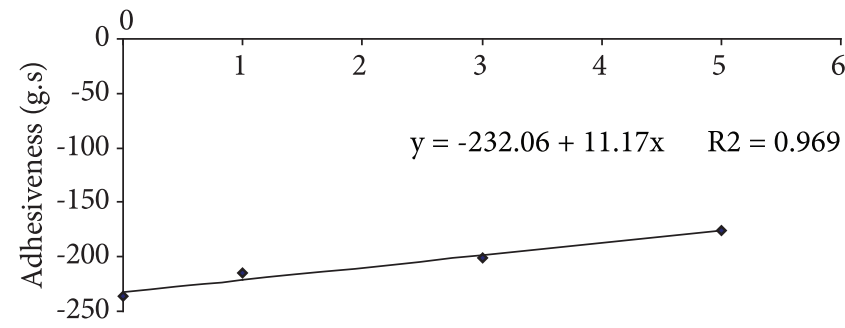

Time (months)

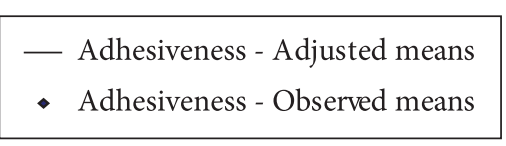

Figure 5. Graphic representation, regression equation and coefficient of determination of the adhesiveness as a function of storage time. 


\section{Conclusions}

The different types of packaging did not interfere in the stability of the guava preserves until the $5^{\text {th }}$ month of storage - time being the factor that most influences the quality of preserves when stored under temperature and humidity of $19.6{ }^{\circ} \mathrm{C}$ and $76.2 \%$, respectively. The presence of potassium sorbate caused an increase in the level of soluble solids and a decrease of the water activity in the preserves. Regardless of the treatment, the preserves remained microbiologically stable during storage. Therefore, with this work, it can be concluded that it is not viable to add potassium sorbate to preserve guava preserves for 150 days, and that the criterion for the choice of packaging should be for the most economically viable, since the packaging factor also did not interfere. However, works with a longer evaluation time are suggested for better determination of the effects of the variables studied.

\section{References}

ADANS, J. B.; ONGLEY, M. J. The degradation of anthocyanins in canned strawberries. I. The effect of various processing parameters on the retention of pelargonidin 3-glucoside. Journal Food Technology, v. 8, p. 139-145, 1973. http://dx.doi. org/10.1111/j.1365-2621.1973.tb01699.x

ALVES, R. M. et al. Effect of light and packages on stability of spreadable processed cheese. International of Dairy Journal, v. 17, n. 4, p. 365-373, 2007. http://dx.doi.org/10.1016/j.idairyj.2006.04.004

ASSIS, M. M. M. et al. Processamento e estabilidade de geléia de caju. Revista Ciência Agronômica, v. 38, n. 1, p. 46-51, 2007.

ASSOCIAÇÃO BRASILEIRA DASINDÚSTRIASDE ALIMENTAÇÃO. Compêndio de legislação dos alimentos. São Paulo, 1996. 2 v.

ASSOCIATION OF OFFICIAL ANALITICAL CHEMISTRY. Official méthods of analysis of the association of analitical chemstry. $11^{\text {th }}$ ed. Washington: AOAC, 1992. $115 \mathrm{p}$.

BAKKER, J.; TIMBERLAKE, C. F. The mechanism of color changes in point wines. American Jornal of Enology and Viticultural, v. 37, n. 4, p. 288-292, 1986.

BRASIL. Resolução RDC n 34 , de 9 de março de 2001. Regulamento técnico que aprova o uso de aditivos alimentares, estabelecendo suas funções e seus limites máximos para a categoria de alimentos: preparações culinárias industriais. Diário Oficial da República Federativa do Brasil, Poder Executivo, Brasília, DF, 12 mar. 2001.

FERREIRA, D. F. SISVAR - Sistema de análise de variância para dados balanceados: programa de análises estatísticas e planejamento de experimentos. Versão 3.04. Lavras: UFLA, 2000.

FIZMAN, S. M.; DURAN, L. Effect of fruit pulps and sucrose on the compression response of different polysaccharides gel systems. Carbohydrate Polymers, v. 17, n. 1, p. 11-17, 1992. http://dx.doi. org/10.1016/0144-8617(92)90018-L

GARCIA-VIGUERA, C. et al. Color stability of strawberry jam as affected ay cultivar and storage temperature. Journal of Food Science, v. 64, n. 2, p. 234-247, 1999. http://dx.doi. org/10.1111/j.1365-2621.1999.tb15874.x

GERSCHENSON, L. M.; ALZAMORA, S.; CHIRIFE, J. Stability of sorbic acid in model food systems of reduced warter activity: sugar solutions. Journal Food Science, v. 51, n. 4, p. 1028-1031, 1986. http://dx.doi.org/10.1111/j.1365-2621.1986.tb11225.x

GIESE, J. Color measurement in foods as a quality parameter. Food Technology, v. 54, n. 2, p. 62-63, 1996.
GLIEMMO, M. F; CAMPO, C. A.; GERSCHENSON, L. N. Effect of several humectants and potassium sorbato on the growth of Zygosaccharomyces balli in model aqueous systems resembling low sugar products. Journal of Food Engineering, v. 77, n. 4, p. 761-770, 2006. http://dx.doi.org/10.1016/j.jfoodeng.2005.08.001

INSTITUTO ADOLFO LUTZ. Normas analíticas do Instituto Adolfo Lutz: métodos químicos e físicos para análise de alimentos. São Paulo: IAL, 1985. 533 p.

JACKIX, M. H. Doces, geléias e frutas em calda. São Paulo: Ícone, 1988. $172 \mathrm{p}$.

JAIME, S. B. M. et al. Estabilidade do molho de tomate em diferentes embalagens de consumo. Ciência e Tecnologia de Alimentos, v. 18 , n. 2 , p. 193-199, 1998. http://dx.doi.org/10.1590/S010120611998000200010

KANNAN, S.; THIRUMARAN, A. S. Studies on the storage life of jamum (Syzygium cuminii Rom.) fruit products. Journal Food Science Technology, v. 41, n. 2, p. 186-188, 2004.

MENEZES, C. C. et al. Caracterização física e físico-química de diferentes formulações de doce de goiaba (Psidium guajava L.) da cultivar Pedro Sato. Ciência e Tecnologia de Alimentos, v. 2, n. 3, p. $618-625,2009$.

MORI, E. M.; YOTSUYANAGI, K.; FERREIRA, V. L. F. Análise sensorial de goiabadas de marcas comerciais. Ciência e Tecnologia de Alimentos, v. 18, n. 1, p. 105-110, 1998. http://dx.doi. org/10.1590/S0101-20611998000100022

MOUQUET, C. et al. Influence of incial $\mathrm{pH}$ on gelation kinetics of texturized passion fruit pulps. Lebensmittel Wissenschaft und Technology, v. 30, n. 1-2, p. 129-134, 1997. http://dx.doi. org/10.1006/fstl.1996.0143

MOUQUET, C.; DUMA, J. C.; GUILBERT, S. Texturization of sweetened mango pulp: optimization using response surface methodology. Journal Food Science, v. 57, n. 6, p. 1395-1400, 1992. http://dx.doi.org/10.1111/j.1365-2621.1992.tb06867.x

NASCIMENTO, M. R. F.; OLIVEIRA, L. F.; BORGES, S. B. Estudo da conservação de doce de corte de casca do maracujá à temperatura ambiente. In: CONGRESSO BRASILEIRO DE CIÊNCIA E TECNOLOGIA DE ALIMENTOS, 13., Porto Alegre, 2002. Anais... Porto Alegre: CBCTA, 2002. 1 CD-ROM.

PADULA, M.; RODRIGUEZ-AMAYA, D. B. Changes in individual carotenoids and vitamin $C$ on processing and storage of guava juice. Acta Alimentaria, v. 16, n. 3, p. 209-216, 1987.

PIMENTEL-GOMES, F. Curso de estatística experimental. 13. ed. Piracicaba: Nobel, 1990. 467 p.

POLICARPO, V. M. N. et al. Green umbu (Spondias tuberosa Arr. Cam.) preserve: physical, chemical and microbiological changes during store. Journal of Food Processing and Preservation, v. 31, n. 2, p. 201-210, 2007a. http://dx.doi.org/10.1111/j.17454549.2007.00124.x

POLICARPO, V. M. N. et al. Estabilidade da cor de doces em massa da polpa de umbu. Ciência e Agrotecnologia, v. 31, n. 4, p. 1102-1107, 2007b.

SANSÓN, R. A. Introduction to food and airbourne fungi. Denmark: Techinal University of Denmark, 2000. p. 283-313.

SATO, A. C. K.; SANJINEZ-ARGANDOÑA, E. J.; CUNHA, R. L. Avaliação das propriedades físicas, químicas e sensorial de preferência de goiabas em calda industrializadas. Ciência Tecnologia de Alimentos, v. 24, n. 4, p. 550-555, 2004. http://dx.doi. org/10.1590/S0101-20612004000400012

SATO, A. C. K.; SANJINÉZ-ARGANDONÃ, E. J.; CUNHA, R. L. The effect of addition of calcium and processing temperature 
in the quality of guava in syrup. International Journal of Food Science and Technology, v. 41, n. 4, p. 417-424, 2006. http://dx.doi. org/10.1111/j.1365-2621.2005.01088.x

THAKUR, B. R.; SINGH, R. K.; ARYA, S. S. Chemistry of sorbates - a basic perspective. Food Reviews International, v. 10, n. 1, p. 71-91, 1994. http://dx.doi.org/10.1080/87559129409540986

SILVA, N.; JUNQUEIRA, V. C. A.; SILVEIRA, N, F. A. Manual de análises microbiológicas de alimentos. São Paulo: Varela, 1997. $317 \mathrm{p}$.

SOMERS, T. C. The polymeric nature of wine pigments. Phytochemistry, v. 10 , n. 9 , p. 2175-2186, 1971. http://dx.doi.org/10.1016/S00319422(00)97215-7

STILES BATTEY, A.; DUFFY, S.; SCHAFFNER, D. Modelling yeast spoilage in cold filled ready to drink beverages with Saccharomyces cerevisiae, Zygosaccharomyces bailii and Candida lipolytica. Applied and Enviromental Microbiology, v. 68, p. 1901-1906, 2002. http://dx.doi.org/10.1128/AEM.68.4.1901-1906.2002

VIDYASAGAR, K.; ARYA, S. S. Stability of sorbic acid in orange squash. Journal Agriculture Food Chemistry, v. 31, n. 6, p. 1262, 1983. http://dx.doi.org/10.1021/jf00120a029

WICKLUND, T. et al. Antioxidant capacity and colour of strawberry jam as influenced by cultivar and storage conditions. Lebensmittel Wissenschaft und Technology, v. 38, n. 4, p. 387-391, 2005.

WITHY, L. M. et al. Storage changes in anthocyanin content of red raspberry juice concentrate. Journal Food Science, v. 58, n. 1, p. 190-192, 1993. http://dx.doi.org/10.1111/j.1365-2621.1993. tb03241.x 